\title{
PENGARUH PENGGUNAAN MEDIA KOMPUTER DENGAN MEMANFAATKAN SOFTWARE PRESENTASITERHADAP HASIL BELAJAR MATEMATIKA SISWA DITINJAU DARI AKTIVITAS BELAJAR SISWA
}

\author{
Arif Ganda Nugroho
}

\begin{abstract}
Abstrak
Penelitian ini bertujuan untuk mengetahui, (1) pengaruh penggunaan media komputer dengan pemanfaatan Software Presentasi yaitu Macromedia Flash 8 dan Microsoft Power Point, (2) pengaruh aktivitas belajar siswa terhadap Hasil belajar matematika, dan (3) interaksi antara media komputer dengan pemanfaatan Software Presentasi dan aktivitas belajar siswa terhadap hasil belajar matematika.

Jenis penelitian adalah penelitian eksperimentasi. Populasi dalam penelitian ini adalah semua siswa SMP Negeri 1 Martapura kelas VIII semester 2 tahun ajaran 2015/2016 sebanyak 6 kelas. Sampel dalam penelitian ini adalah siswa kelas VIIIA sebagai kelas eksperimen dan siswa kelas VIIIB sebagai kelas kontrol. Teknik pengambilan sampel yang digunakan adalah Cluster Random Sampling. Metode pengumpulan data yang digunakan adalah tes, angket, dan dokumentasi. Teknik analisis data menggunakan uji analisis variansi dua jalan dengan sel tak sama, yang sebelumnya dilakukan uji prasyarat analisis yang menggunakan metode lilliefors untuk uji normalitas dan metode Lavene' Statistic untuk uji homogenitas.

Dari hasil analisis data dengan taraf signifikasi 5\% dipenuhi bahwa: (1) terdapat pengaruh yang signifikan antara siswa yang menggunakan media komputer dengan pemanfaatan Software Presentasi terhadap hasil belajar siswa, dengan $F_{a}=5,058$, (2) terdapat pengaruh aktivitas belajar siswa yang signifikan terhadap hasil belajar siswa, dengan $\mathrm{F}_{\mathrm{b}}=3,540$, dan (3) Tidak terdapat ada pengaruh interaksi yang signifikan pembelajaran yang menggunakan media komputer dengan pemanfaatan Software Presentasi dan aktivitas belajar siswa terhadap hasil belajar matematika siswa, dengan $\mathrm{F}_{\mathrm{ab}}=0,233$.
\end{abstract}

Kata Kunci: media komputer, software presentasi, hasil belajar, aktivitas belajar 
Pengaruh Penggunaan Media Komputer Dengan Memanfaatkan Software Presentasi Terhadap Hasil Belajar Matematika Siswa Ditinjau Dari Aktivitas Belajar Siswa

\section{Pendahuluan}

Kemajuan teknologi mempengaruhi semua lingkup kehidupan, tak terkecuali dunia pendidikan. Pekerjaan yang dikenakan oleh manusia secara manual bisa digantikan dengan mesin. Selain sarana untuk menyajikan informasi, komputer dapat dimanfaatkan diberbagai bidang termasuk bidang pendidikan. Misalnya, pemanfaatan komputer sudah berkembang tidak hanya sebagai alat yang hanya dipergunakan untuk membantu urusan keadministrasian saja, melainkan juga sangat dimungkinkan untuk digunakan sebagai salah satu alternatif dalam pemilihan media pembelajaran. Sebagai contoh dengan adanya komputer multimedia yang mampu menampilkan gambar maupun tulisan yang diam dan bergerak serta bersuara, sudah saatnya komputer dijadikan sebagai salah satu alternatif pilihan media pembelajaran yang efektif dan menarik. Hal semacam ini perlu ditanggapi secara positif oleh para guru sekolah menengah, khususnya guru bidang studi matematika, sehingga komputer dapat menjadi salah satu alternatif media yang dapat digunakan dalam proses pembelajaran.

Keberhasilan seorang siswa dalam mempelajari matematika ditandai dengan hasil belajar. Hasil belajar seorang siswa akan dipengaruhi oleh banyak faktor baik dari dalam siswa maupun dari luar diri siswa. Salah satu faktor dari dalam adalah aktivitas belajar siswa. Aktivitas belajar siswa merupakan salah satu faktor penting dalam kegiatan belajar mengajar.

Belajar matematika adalah proses dimana matematika itu ditemukan dan dibangun manusia, sehingga dalam pembelajaran matematika harus lebih dibangun oleh siswa dari pada ditanamkan oleh guru. Perlu dicarikan formula pembelajaran yang tepat, sehingga dapat meningkatkan aktivitas belajar pada siswa. Para guru terus berusaha menyusun dan menerapkan berbagai metode yang bervariasi agar siswa tertarik dan bersemangat dalam belajar matematika. Salah satunya dengan menggunakan media komputer yaitu pemanfaatan Software Presentasi. 
Mengingat pentingnya aktivitas belajar siswa dalam kegiatan belajar mengajar, guru diharapkan dapat menciptakan situasi belajar mengajar yang lebih banyak melibatkan aktivitas belajar siswa, salah satunya dengan memanfaatkan Software Presentasi di dalam pembelajaran. Sedangkan siswa itu sendiri hendaknya dapat aktif dalam kegiatan aktivitas belajar mengajar. Dengan adanya aktivitas ini kemungkinan besar hasil belajar yang dicapai siswa akan memuaskan.

Berdasarkan uraian di atas maka penulis mencoba meneliti penggunaan media komputer dengan memanfaatkan Software Presentasi apakah ada perbedaan hasil belajar matematika yang menggunakan media komputer dengan pemanfaatan Software Presentasi ditinjau dari aktivitas belajar siswa. Dengan penggunaan media komputer dengan memanfaatkan Software Presentasi diharapkan bisa lebih menarik dan interaktif sehingga dapat digunakan sebagai salah satu solusi untuk meningkatkan kualitas pembelajaran .

\section{Metode Penelitian}

Penelitian yang dilakukan merupakan penelitian eksperimentasi yaitu penelitian yang dilakukan dengan sengaja untuk mengusahakan timbulnya variabel-variabel, dalam hal ini adalah pembelajaran yang menggunakan media komputer dengan Software Presentasi dan aktivitas belajar siswa, untuk selanjutnya dilihat pengaruhnya terhadap variabel lain yaitu hasil belajar siswa. Penelitian ini dilakukan dengan membagi subjek menjadi dua kelompok, yaitu kelompok eksperimen dan kelompok kontrol. Pada kelompok eksperimen dikenai perlakuan pembelajaran yang menggunakan media pembelajaran dengan Software Macromedia Flash 8 , sedangkan pada kelompok kontrol dikenai dengan perlakuan pembelajaran yang menggunakan media pembelajaran dengan Microsoft Power Point.

Penelitian ini dilaksanakan di SMP Negeri 1 Martapura Kabupaten Banjar. Alasan peneliti mengambil tempat penelitian di sini adalah sekolah ini dekat dengan tempat tinggal peneliti, siswa di sekolah ini juga banyak 
Pengaruh Penggunaan Media Komputer Dengan Memanfaatkan Software Presentasi Terhadap Hasil Belajar Matematika Siswa Ditinjau Dari Aktivitas Belajar Siswa

(untuk kelas VIII terdiri 6 kelas) serta guru matematika berjumlah 4 orang sehingga peneliti tidak mengalami kesulitan untuk datang ke lokasi penelitian, menentukan jadwal dan materi penelitian, serta berkonsultasi dengan pihak guru maupun sekolah.

Penelitian ini dilaksanakan bulan Maret - Mei 2016 semester genap tahun ajaran 2015/2016. Penelitian ini dilaksanakan sebanyak 6 kali pertemuan. Populasi dalam penelitian ini adalah seluruh siswa kelas VIII SMP Negeri 1 Martapura yang berjumlah 6 kelas. Berdasarkan hasil pengacakan, kelas VII A terpilih sebagai kelas kelompok eksperimen yaitu kelas yang diajar dengan menggunakan media pembelajaran Macromedia Flash 8 berjumlah 40 siswa, sedangkan kelas VII B sebagai kelompok kontrol kelas yang di ajar menggunakan media pembelajaran dengan Microsoft Power Point sebanyak 40 siswa. Sebelum diberi perlakuan, kedua kelompok tersebut harus diuji dahulu apakah kelompok eksperimen dan kelompok kontrol dalam keadaan seimbang. Untuk menguji keseimbangan tersebut dilakukan dengan menggunakan Uji Matching (uji keseimbangan). Uji Matching ini berdasarkan nilai matematika pada ujian akhir semester (nilai raport). Tujuan uji ini untuk mengetahui kemampuan awal siswa dari kedua kelas seimbang. Untuk menguji keseimbangan tersebut digunakan uji t.

Terdapat dua macam variabel dalam penelitian ini, yaitu variabel independen (variabel bebas) dan varibel dependen (variabel terikat). Variabel bebas yaitu media pembelajaran yang terdiri atas media pembelajaran Macromedia Flash 8 dan Microsoft Power Point $\left(X_{1}\right)$ dan Aktivitas Belajar Siswa $\left(\mathrm{X}_{2}\right)$. Sementara itu, yang menjadi variabel terikat yaitu hasil belajar siswa.

Teknik Pengumpulan data dalam penelitian ini adalah tes tertulis. Sedangkan instrumen penelitian yang digunakan dalam penelitian ini adalah instrumen tes bentuk objektif yang mengukur hasil belajar siswa pokok bahasan prisma dan limas. Tes diberikan kepada kedua kelompok. 
Pengumpulan data hasil belajar matematika siswa dilakukan dengan memberikan tes objektif kepada siswa dengan batasan waktu tertentu. Dalam penyusunan instrumen tes, terlebih dahulu disusun kisi - kisi soal kemudian menyusun soal beserta kunci jawaban. Selanjutnya pedoman pemberian skor tiap soal. Sebelum soal tes digunakan, soal tes terlebih dahulu dinilai validitas dan di estimasi reliabilitas.

Teknik Pengumpulan data yang lain dalam penelitian ini adalah menggunakan angket. Angket merupakan metode penelitian dengan menggunakan daftar pertanyaan yang harus dijawab oleh siswa yang menjadi pokok penelitian. Metode angket yang digunakan adalah pilihan ganda. Suatu bentuk angket dimana siswa memilih jawaban yang disediakan. Selain angket peneliti juga menggunakan metode dokumentasi Metode dokumentasi adalah mencari data mengenai hal-hal atau variabel yang berupa catatan, majalah, prestasi, notulen rapat, agenda dan lain sebagainya. Metode dokumentasi pada penelitian ini digunakan untuk memperoleh data siswa atau nama-nama siswa dan daftar nilai (raport).

Dalam penelitian ini, diselidiki efektifitas penggunaan dari penerapan media komputer dengan memanfaatkan Software Presentasi. Batasan yang digunakan dalam menentukan efektif atau tidaknya penerapan suatu media komputer dilihat dari ketuntasan siswa secara klasikal dengan menggunakan acuan Kriteria Ketuntasan Minimal (KKM). Kedua media komputer baik menggunakan Macromedia Flash 8 maupun Microsoft Power Point ini dikatakan efektif jika skor memenuhi KKM yang ditentukan yaitu 65 atau lebih besar dari 64,99.

Pada uji normalitas ini digunakan metode Liliefors. Dalam penelitian ini untuk menguji homogen tidaknya sampel menggunakan Levene Statistic dengan menggunakan bantuan SPSS 17. Sedangkan teknik analisis data hasil belajar siswa Dalam penelitian ini menggunakan analisis variansi dengan dua jalan dengan sel tidak sama. Analisis variansi dua jalan bertujuan untuk menguji perbedaan efek (pengaruh) 2 variabel bebas yaitu media pembelajaran dalam hal ini media komputer (faktor A) dan aktivitas belajar 
Pengaruh Penggunaan Media Komputer Dengan Memanfaatkan Software Presentasi Terhadap Hasil Belajar Matematika Siswa Ditinjau Dari Aktivitas Belajar Siswa

(faktor B) serta interaksi antara media pembelajaran dengan aktivitas belajar siswa (faktor $A B$ ) terhadap variabel terikatnya.

Data yang dikumpulkan untuk dianalisis dalam penelitian ini adalah data hasil belajar siswa melalui tes dalam bentuk soal objektif. Jadi, terdapat dua kelompok data sebagai hasil pengukuran yang akan dianalisis secara simultan. Kedua kelompok yaitu kelompok siswa yang belajar menggunakan media pembelajaran Macromedia Flash 8 dan kelompok siswa yang belajar dengan menggunakan media pembelajaran Microsoft Power Point.

\section{Hasil dan Pembahasan}

\section{Deskripsi Data Hasil penelitian}

\section{a. Data Nilai Hasil Belajar Matematika Siswa}

Data hasil belajar matematika diperoleh dari tes yang dikerjakan siswa kelas VIII A sebagai kelas eksperimen yaitu skor tertinggi 89 dan skor terendah 60 dengan nilai rata-rata 75,55 dan standart deviasinya 8,91. Sedangkan pada kelas VIII B sebagai kelas kontrol yaitu skor tertinggi 83 dan skor terendah 60 dengan nilai rata-rata 71,50 dan standart deviasinya 7,83 .

\section{b. Data aktivitas Belajar Siswa}

Data angket aktivitas belajar siswa diperoleh dari sampel penelitian pada kelas kontrol dan kelas eksperimen setelah angket aktivitas belajar siswa diberikan kepada siswa. Dengan bantuan SPSS versi 17 diperoleh diskripsi data sebagai berikut:

1) Pada kelas eksperimen diperoleh aktivitas belajar siswa tertinggi sebesar 93, terendah 74, mean sebesar 83,38 dan standar deviasi sebesar 4,84 .

2) Pada kelas kontrol diperoleh aktivitas belajar siswa tertinggi sebesar 87 , terendah 67 , mean sebesar 76,53 dan standar deviasi sebesar 6,06 . 
Hasil uji aktivitas belajar siswa disajikan dalam rangkuman tabel 1 sebagai berikut :

Tabel 1 : Rangkuman Hasil Uji Aktivitas Belajar Siswa

\begin{tabular}{|c|c|c|}
\hline Kategori & Eksperimen & Kontrol \\
\hline Tinggi & 11 Siswa & 13 Siswa \\
\hline Sedang & 18 Siswa & 12 Siswa \\
\hline Rendah & 11 Siswa & 15 Siswa \\
\hline
\end{tabular}

\section{Pengujian Prasyarat Analisis}

\section{a. Uji Normalitas}

Uji normalitas adalah pengujian terhadap normal tidaknya sebaran data yang dianalisis. Dalam hal ini peneliti menggunakan uji Lilliefors pada taraf signifikansi 5\%. Untuk mengetahui normalitas populasi digunakan metode Kolmogorov-Smirnov. Data dikatakan normal apabila $L_{\text {hitung }}<L_{\text {tabel. }}$. Hasil uji normalitas disajikan dalam rangkuman tabel 2 sebagai berikut:

Tabel 2 : Rangkuman Uji Normalitas

\begin{tabular}{|c|l|c|c|c|}
\hline Sumber & \multicolumn{1}{|c|}{ Kelas } & $\mathrm{L}_{\text {hitung }}$ & $\mathrm{L}_{\text {tabel }}$ & Keputusan \\
\hline Aktivitas Belajar & Eksperimen & 0,119 & 0,140 & Normal \\
\cline { 2 - 5 } & Kontrol & 0,124 & 0,140 & Normal \\
\hline Prestasi Belajar & Eksperimen & 0,120 & 0,140 & Normal \\
\cline { 2 - 5 } & Kontrol & 0,138 & 0,140 & Normal \\
\hline
\end{tabular}

Dari tabel 2 jelas bahwa $\mathrm{L}_{\text {hitung }}<\mathrm{L}_{\text {tabel }}$ pada taraf signifikasi 5\%. Hasil tersebut membuktikan bahwa sampel tersebut berasal dari populasi yang berdistribusi normal.

\section{b. Uji Homogenitas}

Uji homogenitas adalah suatu pengujian untuk mengetahui apakah antara dua variabel bebasnya mempunyai variansi yang sama atau tidak. Uji homogenitas yang digunakan dalam penelitian ini adalah uji Levene Statistic. Dari perhitungan untuk homogenitas menggunakan SPSS versi 17 didapat bahwa nilai probabilitas Levene Statistic tes hasil belajar $F_{\text {hitung }}=0,844<F_{\text {tabel }}=2,370$ dan probabilitas 
Pengaruh Penggunaan Media Komputer Dengan Memanfaatkan Software Presentasi Terhadap Hasil Belajar Matematika Siswa Ditinjau Dari Aktivitas Belajar Siswa

$=0,523>0,05$, maka $\mathrm{H}_{0}$ diterima yang berarti bahwa kedua sampel mempunyai varian yang sama homogen.

\section{Pengujian Hipotesis}

\section{a. Anava Dua Jalan Dengan Sel Tidak Sama}

Hasil perhitungan analisis variasi dua jalan dengan sel tidak sama dengan taraf signifikansi $\alpha=5 \%$ menggunakan SPSS versi 17 disajikan tabel 3 berikut ini:

Tabel 3 : Hasil Analisis Anava Dua Jalan Dengan Sel Tidak Sama

\begin{tabular}{|l|c|c|c|c|c|c|c|}
\hline $\begin{array}{l}\text { Sumber } \\
\text { Variansi }\end{array}$ & Jk & df & Rk & F $_{\text {hitung }}$ & $\mathbf{F}_{\text {tabel }}$ & Sig & Keputusan \\
\hline Metode & 339,873 & 1 & 339,873 & 5,058 & 4,000 & 0,027 & Ditolak \\
Aktivitas & 475,707 & 2 & 237,854 & 3,540 & 3,150 & 0,034 & Ditolak \\
Interaksi & 31,280 & 2 & 15,640 & 0,233 & 3,150 & 0,793 & Diterima \\
Error & 4972,100 & 74 & 67,191 & - & - & - & \\
Total & 438284,000 & 80 & - & - & - & - & \\
\hline
\end{tabular}

Dari tabel 3 di atas tampak bahwa:

1) $F_{\text {hitung }}=5,058>F_{\text {tabel (1;74) }}=4,000$ dan probabilitas $=0,027<0,05$ maka $\mathrm{H}_{\mathrm{OA}}$ ditolak, sehingga terdapat pengaruh yang signifikan antara siswa yang menggunakan media pembelajaran dengan Software Macromedia Flash 8 dan Microsoft Power Point terhadap hasil belajar siswa.

2) $F_{\text {hitung }}=3,540>F_{\text {tabel (2;74) }}=3,150$ dan probabilitas $=0,034<0,05$, maka $\mathrm{H}_{\text {Ов }}$ ditolak, sehingga terdapat pengaruh aktivitas belajar siswa yang signifikan terhadap hasil belajar siswa.

3) $F_{\text {hitung }}=0,233<F_{\text {tabel (2;7) }}=3,150$ dan probabilitas $=0,793>0,05$, maka $\mathrm{H}_{\mathrm{OAB}}$ diterima, sehingga tidak terdapat interaksi yang signifikan antara media pembelajaran dan aktivitas belajar siswa terhadap hasil belajar siswa.

b. Uji Lanjut Anava

Dari penelitian ini untuk mengetahui manakah dari perlakuan itu yang secara signifikan berbeda dengan yang lain dilakukan uji pasca lanjut jika data bersifat normal dan homogen. 
Dari hasil uji lanjut berdasarkan uji Scheffe diperoleh hasil :

1) Perbedaan rata-rata aktivitas belajar siswa tinggi-rendah kedua kelompok sebesar 5,62 dengan probabilitas sebesar 0,018.

2) Perbedaan rata-rata aktivitas belajar siswa tinggi-sedang kedua kelompok sebesar 4,62 dengan probabilitas sebesar 0,043.

3) Perbedaan rata-rata aktivitas belajar siswa sedang-rendah kedua kelompok sebesar 1,01 dengan probabilitas sebesar 0,649.

Dari ketiga perbedaan rata-rata di atas bahwa pada kelompok belajar siswa tinggi-rendah nilai probabilitasnya $<0,05$. Sehingga dapat disimpulkan bahwa hasil belajar matematika dipengaruhi oleh penerapan media pembelajaran Macromedia Flash 8 dan aktivitas belajar siswa yang berbeda menunjukkan perbedaan yang nyata terhadap hasil belajar matematika.

\section{Pembahasan Hasil Penelitian}

\section{a. Hipotesis Pertama}

Dari hasil anava dua jalan dengan sel tidak sama diperoleh $\mathrm{F}_{\text {hitung }}$ $=5,058>F_{\text {tabel (1;74) }}=4,000$ dan probabilitas $=0,027<0,05$ dengan $\alpha=5 \%$. Dengan demikian $\mathrm{H}_{\mathrm{OA}}$ ditolak sehingga $\mathrm{H}_{1 \mathrm{~A}}$ diterima. $\mathrm{Hal}$ ini berarti terdapat pengaruh yang signifikan antara siswa yang menggunakan media komputer dengan pemanfaatan Software Presentasi terhadap hasil belajar siswa.

Dalam proses pembelajaran dengan menggunakan media komputer dengan pemanfaatan Software Macromedia Flash 8 dapat dengan mudah membangkitkan dan merangsang siswa untuk aktif dalam proses pembelajaran dan tidak memperkecil arti pokok pembelajarannya, tetapi justu membantu memperjelasnya. Dengan media komputer yang memanfaatkan Software Macromedia Flash 8 dapat menggambarkan secara nyata contoh penerapannya dalam kehidupan sahari-hari. Misalkan pada materi melukis prisma dan limas, pada materi ini dibuat dengan animasi gambar yang bergerak layaknya kita menggambar pada kertas gambar terlihat nyata seperti dalam 
Pengaruh Penggunaan Media Komputer Dengan Memanfaatkan Software Presentasi Terhadap Hasil Belajar Matematika Siswa Ditinjau Dari Aktivitas Belajar Siswa

kehidupan sehari-hari. Selain itu bentuk prisma dan limas yang diberi animasi gambar Ka’bah dan Piramida.

Sedangkan siswa yang diberi pengajaran dengan menggunakan media komputer yang memanfaatkan Microsoft Power Point, Siswa kurang bisa menggambarkan secara nyata contoh penerapannya dalam kehidupan sahari-hari, karena animasi yang ditampilkan kurang detail. Siswa hanya mendapatkan sedikit gambaran tentang pembelajaran. Mereka hanya dapat melihat gambaran secara umum saja, sehingga menyebabkan hasil belajarnya kurang baik.

Faktor lain yang dapat mempengaruhi hasil belajar siswa adalah adanya peranan guru dan keaktifan siswa dalam proses belajar mengajar, sarana dan prasarana yang digunakan dalam proses belajar mengajar kaitannya dengan penggunaan media komputer yang memanfaatkan Software Macromedia Flash 8 serta lingkungan sekolah yang mendukung.

Adapun peranan guru dalam proses belajar mengajar meliputi : ketepatan waktu dalam masuk kelas maupun keluar kelas dan penggunaan media pembelajaran yang sesuai sehingga siswa lebih mudah memahami materi yang diajarkan. Dari pendapat guru dengan mengajar menggunakan media komputer yang memanfaatkan Software Macromedia Flash 8 lebih baik dan mudah menarik siswa untuk aktif dalam pelajaran matematika sehingga siswa tidak hanya aktif dalam berpikir namun dapat merangsang siswa untuk berani menyampaikan pendapatnya serta siswa dapat mempelajari sendiri materi pelajaran dari media komputer yang memanfaatkan software macromedia flash 8 dirumahnya masing-masing.

Keaktifan siswa dalam proses belajar mengajar, misalnya siswa selalu bertanya kepada guru tentang materi mana yang belum jelas dipahami, sebagai contoh dalam sub pokok bahasan volume prisma dan limas, ada beberapa siswa yang belum dapat membedakan antara 
tinggi alas prisma dengan tinggi prisma itu sendiri dalam perhitungan volume prisma. Kendala dalam penelitian yang tidak mempengaruhi hipotesis ini yaitu siswa dalam memahami satu materi pelajaran membutuhkan waktu yang cukup lama, serta siswa yang pandai kadang-kadang tidak sabar menunggu temannya yang belum selesai mencatat dan memahami materi yang diajarkan guru.

Fasilitas sarana dan prasarana pembelajaran berbasis TIK yang belum mendukung yaitu perangkat komputer Pentium III yang hanya 40 unit komputer di ruang laboratorium komputer dengan jumlah siswa yang cukup banyak yaitu 240 siswa, serta suasana sekolah yang tenang, bersih dan tertib juga dapat mempengaruhi hasil belajar siswa.

Dari hasil perhitungan diperoleh $\mathrm{F}_{\text {hitung }}=5,058>\mathrm{F}_{\text {tabel (1;7) }}=$ 4,000 dan probabilitas $=0,027<0,05$ dengan $\alpha=5 \%$. Dengan demikian $\mathrm{H}_{\mathrm{OA}}$ ditolak sehingga terdapat pengaruh hasil belajar matematika. Dari hasil nilai rata-rata total hasil belajar untuk kelompok kontrol adalah 71,50 sedangkan kelompok eksperimen adalah 75,55 maka jelas bahwa pembelajaran dengan menggunakan media komputer dengan pemanfaatan Software Macromedia Flash 8 lebih baik hasil belajarnya dari pada pembelajaran dengan menggunakan media komputer dengan pemanfaatan Microsoft Power Point. Dengan kata lain dapat dikatakan bahwa terdapat pengaruh yang signifikan antara siswa yang menggunakan media komputer dengan pemanfaatan Software Presentasi terhadap hasil belajar siswa.

\section{b. Hipotesis Kedua}

Dari hasil anava dua jalan dengan sel tidak sama diperoleh $F_{\text {hitung }}=3,150>F_{\text {tabel (2;74) }}=3,150$ dan probabilitas $=0,034<0,05$. Dengan demikian $\mathrm{H}_{O B}$ ditolak, sehingga terdapat pengaruh aktivitas belajar siswa yang signifikan terhadap hasil belajar siswa. Aktivitas siswa dalam belajar matematika berbeda-beda. Aktivitas belajar siswa yang tinggi dalam belajar menjadikan semangat dalam mempelajari matematika dan sebaliknya aktivitas belajar siswa yang rendah akan 
Pengaruh Penggunaan Media Komputer Dengan Memanfaatkan Software Presentasi Terhadap Hasil Belajar Matematika Siswa Ditinjau Dari Aktivitas Belajar Siswa

menyebabkan siswa kurang bersemangat dalam belajar. Proses belajar mengajar akan memberikan hasil yang lebih baik bila guru mampu membangkitkan aktivitas belajar siswa.

Dapat dinyatakan bahwa siswa yang memiliki aktivitas belajar yang tinggi memiliki pengaruh yang lebih baik terhadap pencapaian hasil belajar dibanding dengan siswa yang memiliki aktivitas belajar sedang, siswa yang memiliki aktivitas belajar yang sedang memiliki pengaruh yang lebih baik terhadap pencapaian hasil belajar dibanding dengan siswa yang memiliki aktivitas belajar yang rendah.

Hal ini disebabkan adanya media komputer dengan pemanfaatan Software Macromedia Flash 8 yang sebelumnya belum pernah dilakukan oleh gurunya yang dapat menimbulkan daya tarik tersendiri untuk siswa, baik dari kategori aktivitas belajar tinggi, sedang maupun rendah untuk memperhatikan dan memahami materi pelajaran yang diberikan. Dengan siswa tertarik terhadap pelajaran matematika maka siswa akan berperan aktif dalam proses belajar mengajar, misalnya siswa aktif dalam bertanya, mencatat, mengerjakan soal, mempelajari kembali catatan matematika mereka. Sehingga ada perbedaan antara siswa dengan aktivitas belajar tinggi, sedang dan rendah terhadap hasil belajar. Dengan kata lain dapat diartikan ada pengaruh antara aktivitas belajar terhadap hasil belajar.

\section{c. Hipotesis Ketiga}

Dari hasil anava dua jalan dengan sel tidak sama diperoleh $F_{\text {hitung }}=0,233<F_{\text {tabel }(2 ; 74)}=3,150$ dan probabilitas $=0,793>0,05$. Dengan demikian $\mathrm{H}_{\mathrm{OAB}}$ diterima, sehingga tidak ada interaksi antara pembelajaran dengan pemanfaatan media komputer dengan pemanfaatan Software Presentasi dan aktivitas belajar siswa terhadap hasil belajar siswa.

Hal ini berarti bahwa pada variasi media komputer dengan pemanfaatan Software Presentasi dan variasi kategori aktivitas belajar 
siswa tidak terjadi kecenderungan yang konsisten. Artinya siswa yang berprestasi tinggi belum tentu berasal dari kombinasi pembelajaran dengan media komputer yang memanfaatkan Software Macromedia Flash 8 aktivitas belajar sedang atau rendah. Demikian pula kalau dilihat pada siswa yang diberi pengajaran dengan media komputer yang memanfaatkan Microsoft Power Point. Disini siswa berprestasi tinggi belum tentu berasal dari kombinasi pembelajaran dengan media Macromedia Flash 8 dan Microsoft Power Point serta aktivitas tinggi tetapi mungkin juga berasal dari kombinasi media Macromedia Flash 8 dan Microsoft Power Point serta aktivitas sedang atau rendah.

\section{d. Kesimpulan Hipotesis}

1) Aktivitas "berpengaruh" terhadap hasil belajar. Siswa-siswa yang aktivitasnya tinggi mempunyai hasil belajar yang lebih baik dibandingkan dengan siswa-siswa yang aktivitasnya sedang, siswasiswa yang aktivitasnya sedang mempunyai hasil belajar yang lebih baik dibandingkan dengan siswa yang aktivitasnya rendah, baik secara umum maupun kalau ditinjau dari jenis media mengajar yang dipakai yaitu pembelajaran menggunakan media komputer yang memanfaatkan Software Macromedia Flash 8 dan Microsoft Power Point.

2) Secara umum media komputer yang memanfaatkan Software Macromedia Flash 8 dan media komputer yang memanfaatkan Microsoft Power Point memberikan efek yang sama terhadap prestasi belajar. Namun kalau dilihat dari masing-masing tingkatan aktivitas media komputer yang memanfaatkan Software Macromedia Flash 8 lebih baik dibandingkan dengan menggunakan media komputer yang memanfaatkan Microsoft Power Point untuk siswa-siswa yang mempunyai aktivitas tinggi dan sedang. Sedangkan untuk siswa-siswa yang mempunyai aktivitas yang rendah yang diberi dengan menggunakan media komputer yang memanfaatkan Microsoft Power Point lebih baik dari pada siswa-siswa yang diberi 
Pengaruh Penggunaan Media Komputer Dengan Memanfaatkan Software Presentasi Terhadap Hasil Belajar Matematika Siswa Ditinjau Dari Aktivitas Belajar Siswa

pengajaran dengan menggunakan media komputer yang memanfaatkan Software Macromedia Flash 8. Penggunaan media komputer yang memanfaatkan Software Macromedia Flash 8 dapat dipelajari siswa sendiri dimanapun dengan didukung komputer Pentium IV tanpa harus melakukan instalasi Software Macromedia Flash 8 sudah bisa dijalankan, dimana materi pelajaran matematika dibuat semenarik mungkin agar siswa tertarik untuk mempelajarinya.

3) Kalau dilihat khusus untuk media komputer yang memanfaatkan Software Macromedia Flash 8 siswa-siswa yang aktivitasnya tinggi lebih baik hasil belajarnya dibandingkan dengan siswa-siswa yang aktivitasnya sedang dan siswa-siswa yang aktivitasnya sedang lebih baik hasil belajarnya dibandingkan dengan siswa-siswa yang aktivitasnya rendah. Keunggulan media komputer yang memanfaatkan Software Macromedia Flash 8 adalah dalam memberikan contoh materi pembelajaran matematika lebih terlihat nyata dikehidupan sehari-hari dalam menampilkan gambar bentuk animasi.

\section{Kesimpulan}

Berdasarkan hasil analisis data dan pembahasan maka dapat ditarik kesimpulan sebagai berikut :

1. Terdapat pengaruh yang signifikan antara siswa yang menggunakan media komputer dengan pemanfaatan Software Presentasi terhadap hasil belajar siswa. Hal ini dapat didasarkan dari analisis data diperoleh $F_{\text {hitung }}=5,058>F_{\text {tabel }}=4,000$ dengan $\alpha=5 \%$. Dapat juga dilihat dari rata-rata nilai hasil belajar matematika siswa yang dikenai pembelajaran dengan dilihat dari rata-rata nilai hasil belajar matematika siswa yang dikenai pembelajaran dengan menggunakan media komputer dengan pemanfaatan Software Macromedia Flash 8 lebih tinggi daripada rata- 
rata nilai hasil belajar siswa yang dikenai media komputer yang memanfaatkan Microsoft Power Point. Dengan demikian disimpulkan bahwa pembelajaran matematika dengan menggunakan media komputer dengan pemanfaatan Software Macromedia Flash 8 lebih baik daripada pembelajaran matematika dengan media komputer yang memanfaatkan Microsoft Power Point.

2. Terdapat pengaruh aktivitas belajar siswa yang signifikan terhadap hasil belajar siswa. Hal ini didasarkan dari analisis data diperoleh $\mathrm{F}_{\text {hitung }}=$ $3,540>\mathrm{F}_{\text {tabel }}=3,150$ dengan $\alpha=5 \%$. Dengan demikian disimpulkan bahwa semakin tinggi aktivitas belajar siswa, maka semakin baik hasil yang dicapai dan sebaliknya semakin rendah aktivitas belajar siswa, maka semakin rendah pula hasil belajarnya.

3. Tidak terdapat ada pengaruh interaksi yang signifikan pembelajaran yang menggunakan media komputer dengan pemanfaatan Software Presentasi dan aktivitas belajar siswa terhadap hasil belajar matematika. Hal ini didukung dari penelitian diperoleh $F_{\text {hitung }}=0,233<F_{\text {tabel }}=$ 3,150 dengan $\alpha=5 \%$. Tidak terdapat interaksi ini dapat dilihat dari kenyataan bahwa pengaruh media komputer terhadap hasil belajar matematika tidak tergantung kepada aktivitas belajar siswa. Artinya pada aktivitas tinggi berlaku media komputer dengan pemanfaatan Software Macromedia Flash 8 memiliki hasil yang lebih baik daripada media komputer yang memanfaatkan Microsoft Power Point, pada aktivitas sedang berlaku media komputer dengan pemanfaatan Software Macromedia Flash 8 memiliki hasil yang lebih baik daripada media komputer yang memanfaatkan Microsoft Power Point, dan pada aktivitas rendah berlaku media komputer dengan pemanfaatan Software Macromedia Flash 8 memiliki hasil yang lebih baik daripada media komputer yang memanfaatkan Microsoft Power Point. Pada sisi lain, pengaruh aktivitas siswa terhadap hasil belajar matematika juga tidak tergantung kepada media pembelajaran. 
Pengaruh Penggunaan Media Komputer Dengan Memanfaatkan Software Presentasi Terhadap Hasil Belajar Matematika Siswa Ditinjau Dari Aktivitas Belajar Siswa

\section{Daftar Pustaka}

Ardiyanti, Anisa Aji. 2008. Perancangan Media Pembelajaran Matematika Berbantuan Komputer Denan Pendekatan Kontekstual Pada Pokok Bahasan Aljabar: Skripsi, UMS Tidak Diterbitkan.

Arikunto, Suharsimi. 2006. Prosedur penelitian suatu pendekatan praktik (Edisi Revisi). Jakarta: Rineka Cipta.

Arsyad, Azhar. 2007. Media Pembelajaran. Jakarta: PT Raja Grafindo Persada.

Budiyono. 2000. Statistika Dasar Untuk Penelitian. Surakarta: UNS Press.

Hadi Sutopo, Ariesto. 2002. Animasi dengan Macromedia Flash Berikut Action Script. Jakarta : Salemba Infotek.

Hapsari, Yunita Dwi. 2008. Efektivitas Pembelajaran Matematika Menggunakan Media Gambar Dengan Bantuan Power Point Ditinjau dari aktivitas Belajar Siswa Kelas VIII SMP NEGERI I MIRI SRAGEN. Skripsi, UMS Tidak Diterbitkan.

Hamalik, Oemar. 2007. Kurikulum dan Pembelajaran. Jakarta: Bumi Aksara.

Jayanti, Risma. 2007. Perancangan Media Pembelajaran Matematika Berbasis Teknologi Informasi dan Komunikasi (TIK) Di Sekolah Menengah Atas Pada Pokok Bahasan Logaritma. Skripsi, UMS Tidak Diterbitkan.

Sugiyono. 2006. Metode Penelitian Pendidikan. Bandung: Alfabeta.

Sardiman. 2001. Interaksi dan Motivasi Belajar Mengajar. Jakarta: Raja Grafindo Persada.

Sukmadinata, Nana S. 2006. Metode Penelitian Pendidikan. Bandung : Remaja Rosdakarya.

\section{Arif Ganda Nugroho}

Dosen Pendidikan Matematika Universitas Muhammadiyah Banjarmasin

E-mail: arif.gnugroho@gmail.com 